\title{
Impact Strength in Dinamic Bending as a Function of the Strength in Static Bending of Wood
}

\author{
Emily da Silveira ${ }^{1}$, Tiago Hendrigo de Almeida ${ }^{2}$, Diego Henrique de Almeida ${ }^{2}$, \\ André Luis Christoforo ${ }^{1, *}$, Francisco Antonio Rocco Lahr ${ }^{3}$ \\ ${ }^{1}$ Centre for Innovation and Technology in Composites - CITeC' Department of Civil Engineering (DECiv), \\ Federal University of São Carlos, São Carlos, Brazil \\ ${ }^{2}$ Department of Science and Materials Engineering, University of Sao Paulo, São Carlos, Brazil \\ ${ }^{3}$ Department of Structural Engineering (SET), University of Sao Paulo, São Carlos, Brazil
}

\begin{abstract}
Wood is a natural, renewable and abundant material in Brazilian territory. But its use in civil construction is still commonplace. When compared to materials such as steel and concrete, it has many advantages, such as its resistance to density ratio. Where it is possible to observe a high resistance, equivalent to concrete of high performance with a much smaller density. Due to the heterogeneity of the woods, very different behaviors may occur in response to the various requests. Thus, for a better use of its capacity is essential knowledge of its properties. Among them is impact strength in bending. Impact strength in bending knowledge is fundamental in structures that will be exposed to short-lived impact loads, such as bridges. But due to some factors this is not a mechanical property that is very accessible to most research centers. The objective of this research was to use linear, exponential, logarithmic and geometric regression models to verify if it is possible to obtain a relation between the resistance modulus in the static bending, which is more easily obtained, and the impact strength in bending values. Ten Brazilian wood species were selected and static bending and impact in bending tests were performed according to ABNT NBR 7190:1997. All tests were done in the Wood and Timber Structures Laboratory (LaMEM), in the Department of Structural Engineering of the Engineering School of São Carlos, University of São Paulo. According to the results and the statistical analysis performed, it was possible to conclude that the Strength in static bending does not seem to be a good estimator of the impact strength in bending of wood.
\end{abstract}

Keywords Impact strength, Static Bending, Wood

\section{Introduction}

Physical and mechanical wood characterization has the most important for better utilization of this material, bring development to the build system and to the use of this as a construction material [1-3]. Characterization process follows the procedures of the Brazilian code ABNT NBR 7190:1997 "Timber Structures Design" in its annex B" Determination of Wood properties for Structure Design". So, this code prescribes procedures to determining of properties of wood and design manufacturing of Timber Structures, presenting great importance to the Brazilian wood sector [4-8].

In the item B.16 entitled "Impact Strength in bending", are described the procedures to determining the energy necessary to the rupture of a wood sample presenting

* Corresponding author:

alchristoforo@yahoo.com.br (André Luis Christoforo)

Published online at http://journal.sapub.org/ijme

Copyright $(2018$ The Author(s). Published by Scientific \& Academic Publishing This work is licensed under the Creative Commons Attribution International License (CC BY). http://creativecommons.org/licenses/by/4.0/ specific dimensions in bending, using a test mechanism based on the energy of a pendulum swinging as shown the figures 1 and 2. Figure 1 shows the used machine developed for SIQUEIRA [12] based on a similar machine from the FPL (Forest Product Laboratory). This machine has a pendulum connected in a chain applying the force at the center of the sample supported in two points [9-13].

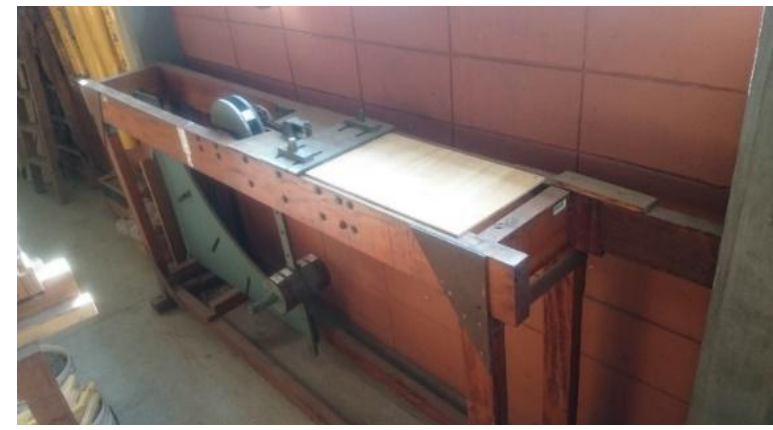

Figure 1. Impact in bending machine

Figure 2 shows the scheme of the used machine for determining the rupture energy. Gravity center of the pendulum presents length equal to $l$ from the rotation axis $\mathrm{O}$. 
When the test is started the pendulum is placed on the height $h i$. The pendulum is abandoned, and the force is applied on the sample through the chain that connects the sample and the pendulum mechanism. Because of the energy absorption in the sample rupture, this difference can be determined gathering the difference between the final position of the pendulum rupturing a sample and without a sample [2].

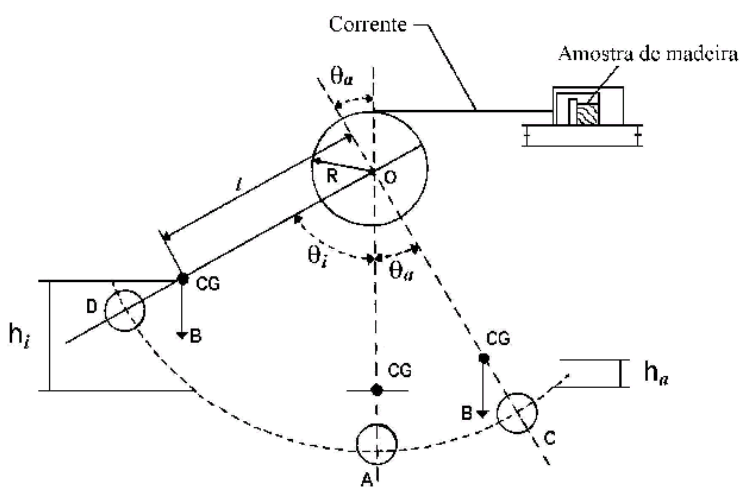

Figure 2. Impact in bending test scheme. Fonte: Stolf [1], adopted from Siqueira [12]

Equations 1 and 2 can be used to calculate the rupture energy $W$ and the impact strength in bending $f_{b w}$, respectively.

$$
W=B l(\cos \theta a-\cos \theta i)
$$

Which: $W$ is the rupture energy $[\mathrm{J}], B$ is the pendulum weight in $[\mathrm{N}], l$ is the pendulum length in $[\mathrm{m}]$, and the final and initial angles.

$$
f_{b w}=\frac{1000 \mathrm{~W}}{b h}
$$

Which: $f_{b w}$ is the impact strength $\left[\mathrm{kN} / \mathrm{m}^{2}\right]$, and $b$ and $h$ are the transversal section of the sample.

This property determination presents some difficulties for the need of a specific machine as shown the figure 1, and because of it, this value is not determined in some cases.

Static bending test shown in the figure 3, can be done using a Universal test machine, being used for determining the conventional value of strength and the modulus of elasticity in static bending [4]. This work was focused on the strength of woos in static bending, and the equation 3 can be used for calculating it.

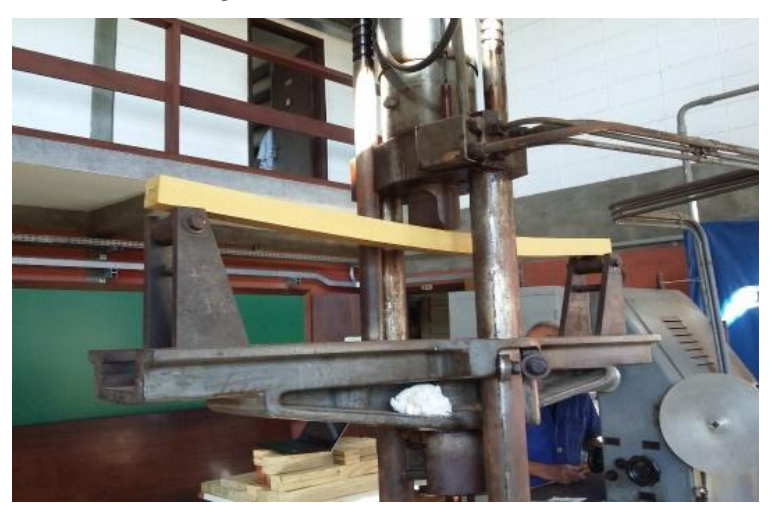

Figure 3. Static bending test

$$
f m=\left(\frac{\left(\frac{F \max }{2}\right)\left(\frac{L}{2}\right)}{\frac{b h^{2}}{12}}\right)\left(\frac{h}{2}\right)
$$

Which: $f m$ is the strength in static bending, Fmax is the rupture, $L$ is the length in static bending, and $b$ and $h$ are the transversal section of the sample.

The objective of this research was to use linear, exponential, logarithmic and geometric regression models to verify if it is possible to obtain a relation between the strength in static bending, which is more easily obtained, and the impact strength in bending values.

\section{Material and Methods}

In order to try estimate the impact strength of wood and the rupture energy through strength of wood in static bending, those testes were carried out using wood gathering the whole range of Strength classes according to the Brazilian code. Table 1 presents these woods as well as their scientific names and correspondent Strength Class. All woods were at $12 \%$ moisture content.

Static bending tests were carried out at the Wood Laboratory and Timber Structures (LaMEM), Department of Structural Engineering (SET), School of Engineering of Sao Carlos, University of Sao Paulo. The equipment used to the static bending was the AMSLER 25,000 kgf, capacity. Impact strength tests were carried out in the same laboratory using an impact in bending machine.

To correlate the values found for rupture energy and impact strength $\left(f_{b w}\right)$ with strength in static bending $\left(f_{m}\right)$ values, regression models were used (equation 4 until equation 7), which "a" and "b" are the parameters of the functions adjusted by the minimum squares method, " $\mathrm{Y}$ " is the independent variable and " $\mathrm{X}$ " is the dependent variable. These equations are about Linear, Exponential, Logarithmic and Geometric regressions, respectively.

$$
\begin{aligned}
Y & =a+b X \\
Y & =a+e^{b X} \\
Y & =a+b \ln (X) \\
Y & =a X^{b}
\end{aligned}
$$

For the determination of the regression model quality, these were evaluated according to analysis of variance (ANOVA); being the non-representativeness of the models admitted as null hypothesis and the representativeness as an alternative hypothesis. The models were considerate with $5 \%$ level of significance $(\alpha)$. For a P-value greater than the level of significance, it was considered that the model is not representative and for a $\mathrm{P}$-value less than $5 \%$, it was considered that the model is representative. To evaluate the correlation between the independent variable and the dependent variable was used the coefficient of determination $\left(\mathrm{R}^{2}\right)$, this way it was possible to determine which of the models considered best fit the relation tested. 
Finally, to calculate and analyze results the Microsoft Excel and Matlab ${ }^{\circledR}$ version 14 were used, respectively.

Table 1. Wood species considered in this work

\begin{tabular}{ccc}
\hline Specie & Scientific Name & Strength Class \\
\hline Cedro & Cedrela fissilis & D20 \\
Cambará Rosa & Erisma sp & D20 \\
Cedro arana & Cedrelinga catenaeformis & D30 \\
Catanudo & Calophyllum sp & D30 \\
Cupiúba & Goupia glabra & D40 \\
Angelim Saia & Parkia pendula & D40 \\
Tatajuba & Bagassa guianensis & D50 \\
Guaiçara & Luetzelburgia sp & D50 \\
Cumaru & Dipteryx odorata & D60 \\
Angelim Vermelho & Dinizia excelsa & D60 \\
\hline
\end{tabular}

\section{Results}

Regression models were used to find a correlation between the determined properties. Linear, exponential, logarithmic and geometric relationships between data were analyzed to find a function that best represents their behavior. Tables 2 to 21 presents the regressions determined for the studied species as well as for each combination of the properties analyzed.

Table 2. Regressions to Cedro - $f_{b w}$

\begin{tabular}{|c|c|c|c|c|}
\hline \multicolumn{5}{|c|}{ Cedro D20 $f_{b w}\left(f_{m}\right)$} \\
\hline & Linear & Exponential & Logarithmic & Geometric \\
\hline a & 402.266 & 465.153 & 120.534 & 342.806 \\
\hline b & 11.410 & 0.0132 & 171.778 & 0.1916 \\
\hline R $^{2}$ & $13.32 \%$ & $6.50 \%$ & $9.67 \%$ & $4.39 \%$ \\
\hline P-value & 0.2433 & 0.4237 & 0.3252 & 0.5135 \\
\hline
\end{tabular}

Table 3. Regressions to Cedro - $W$

\begin{tabular}{|c|c|c|c|c|}
\hline \multicolumn{5}{|c|}{ Cedro D20 $\boldsymbol{W}\left(\boldsymbol{f}_{\boldsymbol{m}}\right)$} \\
\hline & Linear & Exponential & Logarithmic & Geometric \\
\hline a & 436.203 & 486.755 & 324.128 & 429.840 \\
\hline b & 25.063 & 0.0282 & 152.004 & 0.17 \\
\hline $\mathrm{R}^{2}$ & $10.36 \%$ & $4.77 \%$ & $8.20 \%$ & $3.89 \%$ \\
\hline P-value & 0.3076 & 0.4953 & 0.3572 & 0.5391 \\
\hline
\end{tabular}

Table 4. Regressions to Cedro arana $-f_{b w}$

\begin{tabular}{|c|c|c|c|c|}
\hline \multicolumn{5}{|c|}{ Cedro arana D30 $f_{b w}\left(f_{m}\right)$} \\
\hline & Linear & Exponential & Logarithmic & Geometric \\
\hline a & 559.942 & 553.903 & 552.082 & 547.878 \\
\hline b & -0.0296 & -0.0005 & 0.071 & 0.0001 \\
\hline R $^{2}$ & $0.03 \%$ & $0.03 \%$ & $0.00 \%$ & $0.00 \%$ \\
\hline P-value & 0.9571 & 0.9561 & 0.9945 & 0.9994 \\
\hline
\end{tabular}

Table 5. Regressions to Cedro arana - $W$

\begin{tabular}{|c|c|c|c|c|}
\hline \multicolumn{5}{|c|}{ Cedro arana D30 $\boldsymbol{W}\left(\boldsymbol{f}_{\boldsymbol{m}}\right)$} \\
\hline & Linear & Exponential & Logarithmic & Geometric \\
\hline $\mathrm{a}$ & 533.020 & 527.776 & 497.536 & 495.366 \\
\hline $\mathrm{b}$ & 0.2789 & 0.005 & 28.454 & 0.0508 \\
\hline $\mathrm{R}^{2}$ & $0.44 \%$ & $0.44 \%$ & $0.86 \%$ & $0.86 \%$ \\
\hline P-value & 0.8375 & 0.837 & 0.7744 & 0.7737 \\
\hline
\end{tabular}

Table 6. Regressions to Cupiúba - $f_{b w}$

\begin{tabular}{|c|c|c|c|c|}
\hline \multicolumn{5}{|c|}{ Cupiúba D40 $f_{b w}\left(f_{m}\right)$} \\
\hline & Linear & Exponential & Logarithmic & Geometric \\
\hline a & 509.076 & 536.688 & 87.166 & 303.275 \\
\hline b & 16.151 & 0.0217 & 251.847 & 0.34 \\
\hline R $^{2}$ & $69.61 \%$ & $69.16 \%$ & $75.53 \%$ & $75.61 \%$ \\
\hline P-value & 0.0007 & 0.0008 & 0.0002 & 0.0002 \\
\hline
\end{tabular}

Table 7. Regressions to Cupiúba - $W$

\begin{tabular}{|c|c|c|c|c|}
\hline \multicolumn{5}{|c|}{ Cupiúba D40 $\boldsymbol{W}\left(\boldsymbol{f}_{\boldsymbol{m}}\right)$} \\
\hline & Linear & Exponential & Logarithmic & Geometric \\
\hline a & 531.634 & 553.255 & 366.308 & 441.854 \\
\hline b & 37.977 & 0.0511 & 229.923 & 0.3107 \\
\hline $\mathrm{R}^{2}$ & $65.26 \%$ & $64.80 \%$ & $71.85 \%$ & $72.06 \%$ \\
\hline P-value & 0.0015 & 0.0016 & 0.0005 & 0.0005 \\
\hline
\end{tabular}

Table 8. Regressions to Tatajuba $-f_{b w}$

\begin{tabular}{|c|c|c|c|c|}
\hline \multicolumn{5}{|c|}{ Tatajuba D50 $\boldsymbol{f}_{\boldsymbol{b} w}\left(\boldsymbol{f}_{\boldsymbol{m}}\right)$} \\
\hline & Linear & Exponential & Logarithmic & Geometric \\
\hline $\mathrm{a}$ & 912.448 & 889.764 & 912.428 & 899.219 \\
\hline $\mathrm{b}$ & -10.469 & -0.0119 & -41.028 & -0.0525 \\
\hline $\mathrm{R}^{2}$ & $3.69 \%$ & $2.92 \%$ & $2.28 \%$ & $2.29 \%$ \\
\hline P-value & 0.5499 & 0.5957 & 0.6393 & 0.6385 \\
\hline
\end{tabular}

Table 9. Regressions to Tatajuba - $W$

\begin{tabular}{|c|c|c|c|c|}
\hline \multicolumn{5}{|c|}{ Tatajuba D50 $\boldsymbol{W}\left(\boldsymbol{f}_{\boldsymbol{m}}\right)$} \\
\hline & Linear & Exponential & Logarithmic & Geometric \\
\hline $\mathrm{a}$ & 940.723 & --- & --- & 949.843 \\
\hline $\mathrm{b}$ & -35.843 & --- & --- & -0.1577 \\
\hline $\mathrm{R}^{2}$ & $9.34 \%$ & --- & --- & $13.61 \%$ \\
\hline P-value & 0.3339 & --- & --- & 0.2378 \\
\hline
\end{tabular}

Table 10. Regressions to Cumaru - $f_{b w}$

\begin{tabular}{|c|c|c|c|c|}
\hline \multicolumn{5}{|c|}{ Cumaru D60 $f_{b w}\left(f_{m}\right)$} \\
\hline & Linear & Exponential & Logarithmic & Geometric \\
\hline a & $1,672.817$ & $1,760.949$ & $1,797.740$ & $2,350.990$ \\
\hline b & -0.043 & -0.0015 & -37.147 & -0.0931 \\
\hline R $^{2}$ & $0.03 \%$ & $0.67 \%$ & $0.06 \%$ & $0.80 \%$ \\
\hline P-value & 0.9604 & 0.7998 & 0.9399 & 0.7816 \\
\hline
\end{tabular}


Table 11. Regressions to Cumaru - $W$

\begin{tabular}{|c|c|c|c|c|}
\hline \multicolumn{5}{|c|}{ Cumaru C60 $\boldsymbol{W}\left(\boldsymbol{f}_{\boldsymbol{m}}\right)$} \\
\hline & Linear & Exponential & Logarithmic & Geometric \\
\hline $\mathrm{a}$ & $1,637.503$ & $1,716.079$ & $1,671.593$ & $2,014.572$ \\
\hline $\mathrm{b}$ & 0.0483 & -0.0027 & -0.7529 & -0.0712 \\
\hline $\mathrm{R}^{2}$ & $0.01 \%$ & $0.34 \%$ & $0.00 \%$ & $0.49 \%$ \\
\hline P-value & 0.9821 & 0.8568 & 0.9876 & 0.8288 \\
\hline
\end{tabular}

Table 12. Regressions to Cambará Rosa $-f_{b w}$

\begin{tabular}{|c|c|c|c|c|}
\hline \multicolumn{5}{|c|}{ Cambará Rosa D20 $f_{b w}\left(f_{m}\right)$} \\
\hline & Linear & Exponential & Logarithmic & Geometric \\
\hline a & 482.353 & 464.588 & 299.182 & 331.511 \\
\hline b & 19.071 & 0.0362 & 163.068 & 0.3044 \\
\hline $\mathrm{R}^{2}$ & $4.88 \%$ & $5.86 \%$ & $6.67 \%$ & $7.75 \%$ \\
\hline P-value & 0.49 & 0.4484 & 0.4177 & 0.3808 \\
\hline
\end{tabular}

Table 13. Regressions to Cambará Rosa - $W$

\begin{tabular}{|c|c|c|c|c|}
\hline \multicolumn{5}{|c|}{ Cambará Rosa D20 $\boldsymbol{W}\left(\boldsymbol{f}_{\boldsymbol{m}}\right)$} \\
\hline & Linear & Exponential & Logarithmic & Geometric \\
\hline $\mathrm{a}$ & 572.034 & 547.412 & 557.952 & 536.072 \\
\hline $\mathrm{b}$ & 21.017 & 0.0419 & 72.122 & 0.137 \\
\hline $\mathrm{R}^{2}$ & $1.08 \%$ & $1.44 \%$ & $1.62 \%$ & $1.95 \%$ \\
\hline P-value & 0.7475 & 0.7104 & 0.6934 & 0.665 \\
\hline
\end{tabular}

Table 14. Regressions to Catanudo $-f_{b w}$

\begin{tabular}{|c|c|c|c|c|}
\hline \multicolumn{5}{|c|}{ Catanudo D30 $f_{b w}\left(f_{m}\right)$} \\
\hline & Linear & Exponential & Logarithmic & Geometric \\
\hline a & 543.978 & 556.038 & -135.139 & 229.280 \\
\hline b & 0.8624 & 0.0114 & 277.816 & 0.3637 \\
\hline R $^{2}$ & $16.51 \%$ & $15.16 \%$ & $16.29 \%$ & $14.70 \%$ \\
\hline P-value & 0.1898 & 0.2109 & 0.1932 & 0.2185 \\
\hline
\end{tabular}

Table 15. Regressions to Catanudo - $W$

\begin{tabular}{|c|c|c|c|c|}
\hline \multicolumn{5}{|c|}{ Catanudo D30 $\boldsymbol{W}\left(\boldsymbol{f}_{\boldsymbol{m}}\right)$} \\
\hline & Linear & Exponential & Logarithmic & Geometric \\
\hline $\mathrm{a}$ & 542.878 & 554.001 & 129.480 & 321.684 \\
\hline $\mathrm{b}$ & 22.229 & 0.0295 & 276.914 & 0.3656 \\
\hline $\mathrm{R}^{2}$ & $17.46 \%$ & $16.21 \%$ & $16.84 \%$ & $15.46 \%$ \\
\hline P-value & 0.1764 & 0.1943 & 0.1851 & 0.2059 \\
\hline
\end{tabular}

Table 16. Regressions to Angelim Saia - $f_{b w}$

\begin{tabular}{|c|c|c|c|c|}
\hline \multicolumn{5}{|c|}{ Angelim Saia D40 $f_{b w}\left(f_{m}\right)$} \\
\hline & Linear & Exponential & Logarithmic & Geometric \\
\hline a & 156.471 & 467.498 & -941.692 & 177.545 \\
\hline b & 84.830 & 0.0752 & 850.878 & 0.752 \\
\hline R $^{2}$ & $36.85 \%$ & $31.76 \%$ & $33.87 \%$ & $29.03 \%$ \\
\hline P-value & 0.0363 & 0.0563 & 0.0471 & 0.0706 \\
\hline
\end{tabular}

Table 17. Regressions to Angelim Saia - $W$

\begin{tabular}{|c|c|c|c|c|}
\hline \multicolumn{5}{|c|}{ Angelim Saia D40 $\boldsymbol{W}\left(\boldsymbol{f}_{\boldsymbol{m}}\right)$} \\
\hline & Linear & Exponential & Logarithmic & Geometric \\
\hline $\mathrm{a}$ & 702.059 & 777.055 & 551.913 & 685.538 \\
\hline $\mathrm{b}$ & 94.706 & 0.078 & 385.604 & 0.3189 \\
\hline $\mathrm{R}^{2}$ & $9.67 \%$ & $7.20 \%$ & $10.08 \%$ & $7.56 \%$ \\
\hline P-value & 0.3252 & 0.3989 & 0.3146 & 0.3869 \\
\hline
\end{tabular}

Table 18. Regressions to Guaiçara - $f_{b w}$

\begin{tabular}{|c|c|c|c|c|}
\hline \multicolumn{5}{|c|}{ Guaiçara D50 $f_{b w}\left(f_{m}\right)$} \\
\hline & Linear & Exponential & Logarithmic & Geometric \\
\hline $\mathrm{a}$ & $1,227.845$ & $1,191.499$ & $1,120.857$ & $1,045.568$ \\
\hline $\mathrm{b}$ & -0.0157 & 0.0003 & 26.454 & 0.0376 \\
\hline $\mathrm{R}^{2}$ & $0.01 \%$ & $0.02 \%$ & $0.09 \%$ & $0.22 \%$ \\
\hline P-value & 0.9823 & 0.9675 & 0.9282 & 0.8853 \\
\hline
\end{tabular}

Table 19. Regressions to Guaiçara - $W$

\begin{tabular}{|c|c|c|c|c|}
\hline \multicolumn{5}{|c|}{ Guaiçara D50 $\boldsymbol{W}\left(\boldsymbol{f}_{\boldsymbol{m}}\right)$} \\
\hline & Linear & Exponential & Logarithmic & Geometric \\
\hline $\mathrm{a}$ & $1,277.132$ & $1,241.484$ & $1,268.339$ & $1,198.117$ \\
\hline $\mathrm{b}$ & -0.3217 & -0.0017 & -16.707 & 0.0021 \\
\hline $\mathrm{R}^{2}$ & $0.32 \%$ & $0.11 \%$ & $0.03 \%$ & $0.00 \%$ \\
\hline P-value & 0.861 & 0.9174 & 0.9563 & 0.9939 \\
\hline
\end{tabular}

Table 20. Regressions to Angelim Vermelho - $f_{b w}$

\begin{tabular}{|c|c|c|c|c|}
\hline \multicolumn{5}{|c|}{ Angelim Vermelho D60 $f_{b w}\left(f_{m}\right)$} \\
\hline & Linear & Exponential & Logarithmic & Geometric \\
\hline $\mathrm{a}$ & $1,111.231$ & $1,110.014$ & $1,191.683$ & $1,219.337$ \\
\hline $\mathrm{b}$ & -0.0195 & -0.0003 & -23.492 & -0.0288 \\
\hline $\mathrm{R}^{2}$ & $0.05 \%$ & $0.17 \%$ & $0.35 \%$ & $0.59 \%$ \\
\hline P-value & 0.9445 & 0.8991 & 0.8555 & 0.8125 \\
\hline
\end{tabular}

Table 21. Regressions to Angelim Vermelho - $W$

\begin{tabular}{|c|c|c|c|c|}
\hline \multicolumn{5}{|c|}{ Angelim Vermelho D60 $\boldsymbol{W}\left(\boldsymbol{f}_{\boldsymbol{m}}\right)$} \\
\hline & Linear & Exponential & Logarithmic & Geometric \\
\hline $\mathrm{a}$ & $1,100.372$ & $1,098.302$ & $1,146.785$ & $1,159.894$ \\
\hline $\mathrm{b}$ & 0.0067 & -0.0003 & -15.587 & -0.0208 \\
\hline $\mathrm{R}^{2}$ & $0.00 \%$ & $0.02 \%$ & $0.16 \%$ & $0.31 \%$ \\
\hline P-value & 0.9924 & 0.9639 & 0.9031 & 0.8627 \\
\hline
\end{tabular}

As we can see, only to Angelim Saia and Cupiúba $f_{b w}$ values, the models were significant, showing that, in general, the variation of the strength in static bending does not cause effect on the rupture energy values and the impact strength values. These results can be compared with the ones reached by Moreira et al. [13], that evaluated the possibility of estimate those energy parameters using the strength of wood in compression parallel to the grain. It is important to 
outstanding that to Tatajuba rupture energy was not possible to determine the Exponential and Logarithmic models.

\section{Conclusions}

Based on the methodology employed and the results achieved, it was possible to conclude that the conventional value of strength in static bending seems not to be a good estimator of the rupture energy and the impact strength in bending, once most of the model were not significant for the woods considered in this research.

\section{ACKNOWLEDGEMENTS}

Authors thank to CAPES for the financial support and the Wood Laboratory and Timber Structures (LaMEM) of the Engineering of Structures Department (SET) of the Engineering School of Sao Carlos - University of Sao Paulo.

\section{REFERENCES}

[1] Stolf, D. O. ; Ferro, F. S. ; Christoforo, A. L. ; Rocco, F. A. L. Influência do teor de umidade na propriedade de tenacidade de espécies florestais. FLORAM - Revista Floresta e Ambiente, v. 21, p. 501-508, 2014.

[2] Stolf, D. O.; Bertolini, M. S.; Almeida, D. H.; Silva, D. A. L.; Panzera, T. H.; Christoforo, A. L.; Lahr, F. A. R. Influence of growth ring orientation of some wood species to obtain toughness. Revista Escola de Minas, 28 (3): 265-271, 2013.

[3] Steege, H.; Vaessen, R. W.; López, D. C.; Sabatier, D.; Antonelli, A.; Oliveira, S. M.; Pitman, N. C. A.; Jorgensen, P. M.; Salomão, R. P. The discovery of the Amazonian tree flora with an update checklist of all known tree taxa. Scientific Reports, 6(29549): 1-15, 2013.

[4] ABNT NBR 7190:1997. Design of timber structures. Rio de Janeiro, 1997.
[5] Calil Junior, C.; Lahr, F. A. R.; Dias, A. A. Timber elements design. Manole, 2003.

[6] Palludo, D. F. et al. Timber Use in Truss Structures for Roof ("Howe" Type -8 to 18 Meters). International Journal Of Materials Engineering, [s.1.], v. 7, n. 5, p.93-99, 1 out. 2017. Scientific and Academic Publishing. http://dx.doi.org/10.592 3/j.ijme.20170705.03.

[7] Pletz, E. et al. Analyzing the Variability of the Flexural Rigidity in Pre-stressed Laminated Wood Plates. International Journal Of Materials Engineering, [s.1.], v. 7, n. 5, p.88-92, 1 out. 2017. Scientific and Academic Publishing. http://dx.doi.org/10.5923/j.ijme.20170705.02.

[8] Almeida, Diego Henrique de et al. Embedment Parallel to the Grain Strength of the Schizolobium amazonicum Herb Wood Specie. International Journal Of Materials Engineering, [s.1.], v. 7, n. 3, p.52-54, 1 jun. 2017. Scientific and Academic Publishing. http://dx.doi.org/10.5923/j.ijme.20170703.02.

[9] Lahr, F. A. R.; Arroyo, F. N.; Almeida, D. H.; Almeida Filho, F. M.; Mendes, I. S.; Christoforo, A. L. Full characterization of Erisma uncinatum Warm wood specie. International Journal of Materials Engineering. 6(5): 147-150, 2016.

[10] Almeida, T. H.; Almeida, D. H.; Christoforo, A. L.; Chahud, E.; Branco, L. A. M. N.; Lahr, F. A. R. Density as estimator of strength in compression parallel to the grain in wood. International Journal of Materials Engineering, 6(3): 67-71, 2016.

[11] Forest Products Laboratory - USDA. Wood Handbook: Wood as an Engineering Material. Madison: Forest Products Laboratory - USDA, 2010.

[12] Siqueira, M.L. Projeto e construção de máquina para determinação da tenacidade de madeira. São Carlos, 1986. 103p. Dissertação (Mestrado) - Escola de Engenharia de São Carlos, Universidade de Sâo Paulo.

[13] Moreira, A. P. et al. Toughness and Impact Strength in Dynamic Bending of Wood as a Function of the Modulus of Elasticity and the Strength in Compression to the Grain. International Journal Of Materials Engineering, [s.1.], v. 7, n. 4, p.61-67, 1 ago. 2017. Scientific and Academic Publishing. http://dx.doi.org/10.5923/j.ijme.20170704.01. 